\title{
Covid-19: Teleworking, Surveillance and 24/7 Work. Some Reflexions on the Expected Growth of Remote Work After the Pandemic
}

\author{
Ivan Manokha \\ Oxford Department of International Development, University of Oxford, \\ Oxford, Oxfordshire, United Kingdom \\ ivan.manokha@qeh.ox.ac.uk
}

\begin{abstract}
The lockdowns imposed by most governments during the Covid-19 pandemic have resulted in an unprecedented increase in teleworking. This spike in remote work has generally been greeted with enthusiasm by both academic and non-academic commentators and there is now a widely shared view that employers should be encouraged to retain and enhance the teleworking arrangements in the post-pandemic period. This paper examines the spread and normalization of telework during the pandemic with reference to the growth of the $24 / 7$ work culture and the blurring of boundaries between work and private lives that have been developing in the last two decades or so. It is argued that the rise in remote work during the crisis is contributing to the movement towards $24 / 7$ work and to the collapse of the boundary between professional and private life, particularly as a result of remote employee surveillance that comes with telework. It also results in a new form of alienation - the alienation of workers from their private homes.
\end{abstract}

\section{Keywords}

workplace surveillance - remote work - 24/7 work - Covid-19 - alienation - governing

- "the worker ... is at home when he is not working,

and not at home when he is working"

(K. Marx, Economic and Philosophical Manuscripts) 


\section{Introduction}

A spike in telework - in the practice of working from home or remotely ${ }^{1}$ for a certain amount of time determined by the employer - during the Covid-19 pandemic in most Western states has largely been greeted with enthusiasm. In both academic and non-academic literature it has been observed that the adoption of teleworking has demonstrated its viability, and that now telework should become the norm rather than the exception. As, for example, Adams-Prassl et al. observed, while it used to be a luxury' before the pandemic, in the postCovid-19 world working from home will finally become "a new "normal". ${ }^{2}$ It is acknowledged that this will not be possible in all sectors, and that the practice of teleworking involves mostly white-collar jobs which, in turn, means that there may emerge a certain divide between those who can benefit from it and those who will be excluded from telework. ${ }^{3}$ Nevertheless, there is a broad consensus that the share of teleworkers is likely to grow significantly in the post-pandemic world, and this is generally seen as a positive development. ${ }^{4}$ The benefits of

1 While in the past the term 'remote work' used to designate working from a different geographical location on a permanent basis, e.g. a different town or a different country without ever commuting, the terms 'telework' and 'remote work' are now widely used interchangeably (along with new terms such as 'virtual work'), and in this paper they will be used as synonymous as well.

2 Abigail Adams-Prassl, Teodora Boneva, Marta Golin, Christopher Rauh, "Working from Home: The Polarising Workplace," VoxEU.org, September 2, 2020, accessed September 20, 2020,https:// voxeu.org/article/working-home-polarising-workplace.

3 See, for example, Abigail Adams-Prassl, Teodora Boneva, Marta Golin, Christopher Rauh, "Inequality in the impact of the Coronavirus shock: Evidence from real time surveys," Centre for Economic Policy Research, Discussion Paper 14665, April 2020, accessed September 20, 2020, https://cepr.org/active/publications/discussion_papers/dp.php?dpno=14665; Santo Milasi, Martina Bisello, John Hurley, Matteo Sostero, Enrique Fernández-Macías, "The Potential for Teleworking in Europe and the rRisk of a New Digital Divide," VoxEU.org, 14 August 2020, accessed September 20, 2020, https://voxeu.org/article/potential-teleworking-europe-andrisk-new-digital-divide; Alexander W. Bartik, Zoe B. Cullen, Edward L. Glaeser, Michael Luca, Christopher T. Stanton "What Jobs are Being Done at Home During the COVID-19 Crisis? Evidence from Firm-Level Surveys," National Bureau of Economic Research, Working Paper 27422.

4 See also Daniel Thomas, Stephen Morris and Andrew Edgecliffe-Johnson, "The End of the Office? Coronavirus May Change Work Forever," The Financial Times, May 1, 2020 accessed May 15, 2020, https://www.ft.com/content/1b30430o-o756-4774-9263-c97958eoo54d; Justin Harper, "Flexible Working Will Be a New Normal after Virus," BBC News, May 22, accessed May 23, 2020, https://www.bbc.co.uk/news/business-52765165; Tracy Hadden Loh and Lara Fishbane, "COVID-19 Makes the Benefits of Telework Obvious, The Brookings Institution, March 17, 2020, accessed September 20, 2020, https://www.brookings.edu/blog/the-avenue/2020/03/17/ covid-19-makes-the-benefits-of-telework-obvious/. 
remote work for employees that are commonly emphasised include flexibility, increased autonomy, the elimination of the need to commute to work, and the possibility to organise households and family tasks more easily.

Now, when it comes to 'teleworking' or 'remote work', it is first important to explain what exactly we mean when we use these terms. To start with, we may make a distinction between remote work performed by salaried employees, and remote work carried out by individuals that operate in the 'gig' economy (engaged in 'crowdwork' or 'on-demand' platform work) as 'independent contractors. ${ }^{5}$ As regards salaried employees, we may further distinguish between what we may call 'formal' remote work (when employers allow employees not to come to the workplace and work a certain number of hours from home) and it is this type that has greatly increased during the pandemic - and 'informal' remote work (when employees continue working outside regular working hours and outside the workplace in order to meet the demands or because they feel compelled to remain available and reachable).

On the face of it, it does indeed seem that 'formal' telework might be highly beneficial to employees. In the late-modern world, as numerous studies have demonstrated, people work longer hours and more intensely, and suffer from the scarcity of time. As Hartmut Rosa, a sociologist of time, observed, the pace of life in general - the increase of the number of action episodes per unit of time - has accelerated significantly in recent years: some actions are directly accelerated, as in the case of fast food, speed dating, speed reading, power naps or drive-through funerals; pauses between actions are shortened; and, some are actions are compressed in the form of multitasking (the simultaneous performance of several actions). A lot of this has to do with the increased dominance of work imperatives over other needs, with the 'colonization' of family life by work (including via the growth of 'informal' remote work), often expressed by individuals as inability to have 'quality time' with partners, children or friends, which in turn adds to work-related anxiety and stress. Here come Covid-19 lockdowns and a massive adoption of telework, and it is, indeed, tempting to suggest that it might be a solution to some of these problems - more time spent at home with the loved ones, more flexibility in time management, more personal autonomy, etc. The plausibility of this assumption is reinforced by the

5 For more on this, see Valerio De Stefano, "The Rise of the 'Just-In-Time Workforce': On-demand Work, Crowdwork, and Labor Protection in the 'Gig-economy'," Comparative Labor Law \& Policy Journal 37, no. 3, (2016): 471 -503; Antonio Aloisi and Elena Gramano, "Workers Without Workplaces and Unions Without Unity: Non-Standard Forms of Employment, Platform Work and Collective Bargaining," Social Science Research Network, March 21, 2019, accessed June 1, 2020, https://papers.ssrn.com/abstract=3363185. 
fact that during the pandemic remotely working employees found themselves in a clearly more privileged position than those who had to continue on-site work and who thereby were more exposed to the risk of contracting the virus (mostly blue-collar and manual workers).

However, as will be argued below, the spike in teleworking during the pandemic, and its expected persistence after the crisis, should be treated with more caution as telework seems to contribute to the further development of the $24 / 7$ work pattern with its irregular scheduling and with employees expected to be available and reachable outside working hours, to continue working in the evening and on weekends. One of the reasons for this is that telework comes with the extension of employee surveillance from the workplace - which, with the new digital means of surveillance, is becoming truly panoptic ${ }^{6}$ - to private homes of employees. First, this further normalizes digital employee surveillance, and, in particular, the practice of employee monitoring outside the workplace - via different mobile devices - which has been developing in recent years. But, more importantly, it contributes to the further dissolution of the boundary between private life and work, which has been the key device to synchronize linear time of work (working schedules, deadlines, productivity, etc.) with cyclical time (circadian bodily rhythms: hunger, sleeping, eating) and cyclical family rhythms of family life (raising children, their schooling, education, etc.). In addition to this, the paper will also argue that telework introduces a new form of alienation - alienation from one's home - as employees are at home, and yet they are also at work with the employer's 'gaze' penetrating their private spaces.

\section{Time and Work in Traditional, Modern and Late-Modern Societies}

One of the main features of pre-modern societies is the experience and the measurement of time that is related to natural occurences: days, nights, seasons, the waves and tides of the sea, monthly cycles, as well as biological and physiological rhythms of the body such as sleep, hunger and thirst. In the words of Hartmut Rosa, traditional societies are "dominated by a cyclical time consciousness in which time is experienced as a circulation of continuously recurring processes and states of affairs. ... The primary form of experienced time differentiates between before and after [a certain natural process

6 See Ivan Manokha, "The Implications of Digital Employee Monitoring and People Analytics for Power Relations in the Workplace," Surveillance \& Society 18, no. 4 (2020) (forthcoming). 
or occurrence]". ${ }^{7}$ Or, as Henri Lefebvre puts it, cyclic time scales submerged themselves immediately and directly in "cosmic time scales" and gave rhythm to an existence which was organically linked to nature. ${ }^{8}$ Work in such traditional societies is nested in these natural cycles, it is rhythmed and shaped by the natural environment of which individuals are an integral part: farming follows seasonal rhythms, cows must be milked daily, sheep must be attended at lambing time, etc. In other words, human labour is part of the cyclical time experience and, as E.P. Thompson observed, ${ }^{9}$ even the notation of time in such societies is often 'task-oriented', that is, time is related to rounds of agricultural or pastoral tasks, or different domestic chores. The timing and the duration of work are not imposed arbitrarily but follow a natural course as the peasant or labourer "appears to attend upon what is an observed necessity". ${ }^{10}$ In short, there is no distinction between working time and non-working time; there is no boundary between work and private life.

But things change profoundly with the rise of capitalism: with human labour becoming a saleable commodity purchased to create surplus value, and with production being totally subordinated to the profit motive, time itself becomes a commodity. Now it is 'labour time' that is purchased by the employer from the employees and constitutes, as Marx observed, the central value-creating factor of production. Time-thrift and time efficiency become central to the process of production for the ability to produce a commodity in less time leads to higher profits and entrepreneurs or firms that produce more in one unit of time gain a competitive advantage. The increase in productivity - which may described as the reduction in units of time necessary for the production of a commodity - becomes one of the key motives that govern capitalist production. As Adam observed, ${ }^{11}$ when time is understood, and related, to as money, it means that the faster something moves through the system the better it is. Efficiency and profitability on this view are seen as gains, while any unused time is seen as money wasted. Now, this is not to say that in pre-capitalist societies the management of time was unimportant; after all, as Marx himself

7 Hartmut Rosa, Social Acceleration: A New Theory of Modernity (New York: Columbia University Press, 2013), 6.

8 Henri Lefebvre, Rhythmanalysis: Space, Time, and Everyday Life (London: Continuum, 2004), 8.

$9 \quad$ Edward Palmer Thompson, "Time, Work-Discipline, and Industrial Capitalism," Past \& Present, no. 38 (Dec., 1967), 61.

$10 \quad$ Thompson, "Time and Work-Discipline," 62.

11 Barbara Adam, Timescapes of Modernity. The Environment and Invisible Hazards (New York: Routledge, 1998). 
noted in Grundrisse, "economy of time, to this all economy ultimately reduces itself". ${ }^{12}$ But it is only in capitalism that Benjamin Franklin's formula "Time is Money' is rendered possible, as well as other expressions that underline the commodity nature of time such as 'investing time', 'saving time' or 'losing time', and it is only in capitalism that "one can convert time and money into each other like two currencies."13 As a result, working time is no longer nested in cyclical natural processes and occurences; it is now experienced as a linear and abstract magnitude, that is stripped of any qualities or spatial references.

Now, while capitalist production, to quote Marx once more, "drives, by its inherent nature, towards the appropriation of labour throughout the whole of the 24 hours in the day", 14 the working time of each individual worker must be limited to enable the reproduction of his or her labour power, and for social reproduction more generally to be possible. Thus, right from the start one of the objectives of worker movements was to reduce the duration of the working day, to obtain the right not to work on weekends, to have the right to have a paid vacation, etc. Indeed, as Lefebvre observes, "no matter how highly developed an industrial civilization may be, hunger, sleep and sex are still bound up with customs and traditions linked to cyclic time. ... It is unnatural not to sleep at night, not to eat at specific hours, etc."15 The same applies to family life that is governed by cyclic, biological and physiological time scales and cannot be entirely subordinated to linear time. In advanced capitalist societies, the synchronization of the two time scales took the form of a strict separation of fixed working hours from non-working hours, of the workplace from private home. It is especially during the post-war period of growth and prosperity that workers and their organisations succeeded in obtaining various regulations that enabled them to limit the dominance of the linear time over cyclical time.

However, in the late-modern world this form of reconciliation of work and private life has been significantly undermined. As has been observed by a number of authors, we currently live in an era of 'flexible capitalism' which is characetrized by the disruption of the organisation of work based on clearly defined hours of labour and rest, and by the separation of work from free time. ${ }^{16}$ These changes have been produced by a complex set of political,

\footnotetext{
12 Karl Marx, The Grundrisse (New York: Harper \& Row, 1972), 76 (emphasis added).

13 Rosa, Social Acceleration, 377 (endnote 9).

14 Karl Marx, Capital: Volume 1 (London: Pelican Books, 1976), 367.

15 Henri Lefebvre, Critique of Everyday Life, Volume 2: Foundations For a Sociology of the Everyday (London: Verso, 2002), 49.

16 See, for example Luc Boltanski and Ève Chiapello, The New Spirit of Capitalism (London: Verso, 2007); Michael Quinlan, "Precarity and Workplace Well-Being: A General Review," in Safety or Profit? International Studies in Governance, Change and the Work Environment,
} 
economic and technological processes. Thus, since the adoption of neoliberal reforms in the 1970s, the economies in advanced capitalist countries have been characterized by the gradual dismantling of post-war institutions and compromises, and the reassertion of a 'market-based' policy framework. This has enabled the creation of non-standard forms of employment (flexible and irregular schedules, precarious and contingent arrangements, multiple job-holding, etc.) accompanied by the erosion of employment protections and labour rights. In addition, as Rosa observes, ${ }^{17}$ there has been a confluence of three revolutions around 1989: the political revolution, which was marked by the collapse of communism in the Soviet Union and numerous other former socialist countries, the digital revolution forced above all by the establishment of the Internet, and a mobile revolution that enabled microelectronic communicative availability unbound by location.

We may add to this another important development that has affected the nature of work in advanced countries - the increasing tertiarization of their economies. As Anttila and Oinas observe, services are produced and consumed in one act - they cannot be stored like physical products. As a result, the staffing of service production must follow the customer flow, resulting in the flexible use of working time. In addition, as they rightly point out, "the evolving post-industrial working time regime is linked to the 'new economy', characterised by globalization, 24-hour financial markets, informationalisation and networking across time zones"18.

The rise of the 24/7 global economy has been accompanied, as Jonathan Crary has observed, by processes that seek to make a human subject coincide with its imperatives and schedules and render "plausible, even normal, the idea of working without pause, without limits"19. As Anttila and Oinas put it, 24/7 markets are in the process of creating a ' $24 / 7$ society', ${ }^{20}$ which is a 'non-stop society' ${ }^{21}$ in which, the standard working week, is no longer the norm as "flexible working hours, 24/7

ed. Theo Nichols and David Walters (New York: Routledge); Peter Cappelli, The New Deal at Work: Managing the Market-Driven Workforce (Boston: Harvard Business School Press, 1999); Guy Standing, "Understanding the Precariat through Labour and Work Guy Standing." Development and Change 45, no. 5 (2014): 963-980.

17 Rosa, Social Acceleration, 213.

18 Timo Anttila and Tomi Oinas, "Patterns of Working Time and Work Hour Fit in Europe," in Family, Work and Well-Being, ed. Mia Tammelin (Cham: Springer International Publishing, 2018), 51 .

19 Jonathan Crary, 24/7: Late Capitalism and the Ends of Sleep, (London: Verso, 2014), 10.

$20 \quad$ Anttila and Oinas, "Patterns of Working Time", 64.

21 Lucia Reisch, "The Role of Time and Temporalities for Sustainable Patterns of Consumption," Time \& Society 10, no. 2/3 (2001), 370. 
working time, and contract work"22 become more and more widespread. The private sphere is invaded and colonized by work; work imperatives and deadlines dictate the rhythm and the pace of human life dissolving the boundary between professional and private time. 'Lean' production and 'just-in-time' business schedule that seek to compress to the maximum any waste of time lead to the creation of 'just-in-time' employees who are expected to be available whenever needed. In the words of Smith and McBride, ${ }^{23}$ people increasingly live to work instead of working to live. And one of the key social costs of the rise of the $24 / 7$ work that are externalized on employees and their families, has been the increase in what we refer to here as 'informal' remote work. Although there is a lack of empirical studies to measure precisely the extent of this development, some studies that have been undertaken confirm its existence and growth in Western states. Thus, for example in the United States, according to the US Bureau of Labour, on an average day last year, $23.7 \%$ of full-time workers spent at least part of their workday working at home, compared with 18 percent in 2003, and employed people worked an average of 5.4 hours on a weekend day. ${ }^{24}$ In Europe, the last European Working Conditions Survey, carried out in 2015, established that a large proportion of employees worked during non-standard hours and that $22 \%$ of the employed worked in their free time to meet work demands several times a month. ${ }^{25}$

Now, returning to the synchronization of linear and cyclical time, the rise of a 24/7 work pattern, as Crary observes, "undermines distinctions between day and night, between light and dark, action and repose". ${ }^{26}$ Indeed, the cyclical bodily rhythms - eating, resting, sleeping - and cyclical family time are increasingly dominated by linear time of work as employees skip lunches or eat in front of their screens, sleep on average much less than before, and spend less time with children. The synchronisation of the two forms of time-scale that relied on fixed working hours and the shielding of private life from work has thus been undermined. Let us now return to the rise in teleworking during the pandemic and examine its implications.

22 Judy Wajcman, Pressed for Time: The Acceleration of Life in Digital Capitalism, (Chicago: University of Chicago Press, 2014), 75 .

23 Andrew Smith and Jo McBride, "Working to Live, Not Living to Work': Low-Paid Multiple Employment and Work - Life Articulation," Work, Employment and Society, September 2020, https://doi.org/10.1177/o950017020942645.

The US Bureau of Labor Statistics, "Employment Situation Summary," May 2019, accessed July 1, 2020, https://www.bls.gov/news.release/empsit.toc.htm.

25 Eurofound, Sixth European Working Conditions Survey, (Luxembourg: Publications Office of the European Union, 2015).

26 Jonathan Crary, 24/7, 53 . 


\section{Covid-19 and a Rise in 'formal' Telework}

It is tempting to suggest that the growth of 'formal' telework during the pandemic signals a return to the pre-capitalist organisation of work - without the separation of work and private life - which might help employees better reconcile cyclical and linear time. However, it would be an erroneous conclusion. As long as there is a wage-labour relation, "[t]hose who are employed experience a distinction between their employer's time and their own time"27 and the time spent working is not their property, but the property of the employer. The employer gives the tasks to be performed, deadlines to respect, targets to hit, etc. Work imperatives and their schedule continue to dominate bodily and family rhythms. As Thompson further observes, ${ }^{28}$ a return to the pre-capitalist work organisation that is not subject to external and arbitrary time schedule is only possible when workers are independent and own their means of labour. Here we may note in passing in this respect, that perhaps the situation of 'gig' workers working remotely, indeed, resembles the pre-capitalist work as their labour is heavily 'task-oriented' (particularly in the case of 'crowdwork') and they do not depend on the employer to get access to the means of production. Yet, even if they may structure their working time more flexibly (and, for this reason, many of them tend to feel freer, as has been observed in some studies ${ }^{29}$ ), the deadlines are imposed by clients, and their very ability to get a task to perform depends on the market and on their competitiveness in the market.

Now, returning to the rise in 'formal' telework, it seems to reinforce the dissolution of the boundary between work and private life, and to contribute to the further development of $24 / 7$ work. To begin with, telework comes with the extension of workplace surveillance to private homes of employees. Workplace surveillance has always been a structural necessity in capitalism as employers, who purchase human labour, need to ensure that it is used as efficiently as possible. To quote Marx, "the worker works under the control of the capitalist to whom his labour belongs; the capitalist takes good care that the work is done in a proper manner," which, in turn, involves the development of "a barrack-like discipline, which is elaborated into a complete system in the factory, and brings the $[. .$.$] labour of superintendence to its fullest development, thereby dividing$

\footnotetext{
27 Thompson, "Time and Work-Discipline," 61.

28 Thompson, "Time and Work-Discipline," 61.

29 For example, Carl Frey and Michael Osborne, "Technology at Work. The Future of Innovation and Employment," The Oxford Martin School, February 2015, accessed September 20, 2020,https://www.oxfordmartin.ox.ac.uk/downloads/reports/Citi_GPS_ Technology_Work.pdf.
} 
the workers into manual labourers and overseers". ${ }^{30}$ As is often noted, in particular by scholars developing the Labour Process Theory, ${ }^{31}$ the historical development of capitalism from its emergence to the present has been marked by the evolution and perfection of different techniques of workplace surveillance (from simple overseeing of workers by supervisors to Taylorism and 'scientific management' and the rise of human resource management, to modern methods of 'gamification' and digital tracking).

Given the structural necessity for employers to monitor workers, the development of remote work has naturally led to the need to find new techniques of surveillance to oversee employees working from home. Indeed, as noted by CNBC, "with more of their staffers spending the day in their pyjamas, employers have an increasingly difficult task when it comes to figuring how hard employees are working." ${ }^{2}$ In the context of the rising demand for such technologies, developers of the so-called 'user activity monitoring tools' quickly obliged: a whole range of products was created or perfected (for many of these technologies had been created earlier) with the inclusion of new features (e.g. encryption, video conferencing, etc.) to meet the demand. And, unsurprisingly, the firms supplying such solutions (e.g. Prodoscore, Time Doctor, Toggl RescueTime, Hours, Timely, Harvest, Everhour, Timeneye, ClickTime, TopTracker, etc.) were some of the main winners of the pandemic - they registered a dramatic growth of several hundred percent. ${ }^{33}$ And these technologies may be highly invasive. As, for example, reported by The Wall Street Journal already in 2008, some remotely working employees were monitored using software that allowed employers to instantaneously detect anger, raised voices or children crying in the background when employees working from home made

$30 \quad$ Karl Marx, Capital, 549 (emphasis added).

$3^{1} \quad$ See, for example, Harry Braverman, Labor and Monopoly Capital: The Degradation of Work in the Twentieth Century (New York: Monthly Review Press, 1974); Michael Burawoy, Manufacturing Consent: Changes in the Labor Process Under Monopoly Capitalism (Chicago: University of Chicago Press, 1979); Alessandro Gandini, "Labour Process Theory and the Gig Economy," Human Relations 72, no. 6 (2018): 1039-56; Alex Veen, Tom Barratt, and Caleb Goods. "Platform-Capital's 'App-Etite' for Control: A Labour Process Analysis of Food-Delivery Work in Australia," Work, Employment and Society, 34, no. 3 (2020): 388-406. Jessica Golden and Eric Chemi, "Worker Monitoring Tools See Surging Growth as Companies Adjust to Stay-at-Home Orders," CNBC, May, 13, 2020, accessed September 20, 2020, https://www.cnbc.com/2020/o5/13/employee-monitoring-tools-see-uptick-as-morepeople-work-from-home.html.

Richard Bowman, "Stocks for the Remote Working Economy - Winners of COVID-19 Pandemic," Catana Capital, April 15, accessed September 20, 2020, https://catanacapital. com/blog/remote-working-stocks-working-from-home-economy/. 
home-office calls. ${ }^{34}$ These tools have since been perfected and enable employers to watch remote workers much more closely. For example, a prominent technology blog Techdirt, discussed an example of 'domestic surveillance' software - a programme called 'Sneek' - which was becoming particularly popular with employers during the crisis. This software allows managers to build a 'wall of faces' of their remotely working employees - a board of photos of workers that are updated via their laptop camera every one to five minutes and to instantly connect workers in a live video call by clicking on their face, even if the workers in question have not clicked 'accept'. ${ }^{35}$ Another tool that has been very popular with employers during the pandemic is Prodoscore that tracks worker activity without employees being aware of this, and then provides managers with a score on a productivity scale. Prodoscore's developers do recommend that employers tell employees that they are being tracked, but they do not have to and in practice many employers track workers without informing them. ${ }^{36}$

Now, not all surveillance tools are invasive to this extent, but what they all have in common is that they extend, in one way another, the 'gaze' of the employer (whether in the form of actual video monitoring or using other monitoring techniques such as regular screenshots of employee's computer screen, keylogging of all activities, etc.) into their private spaces. In addition to further dissolving the boundary between work and private life, this also normalizes the use of new digital means of surveillance by employers, both inside and outside the workplace, that has rapidly developed in recent years. Within the workplace, these surveillance technologies enable employers to track every movement of employees, record and analyse everything they do, time their pauses and toilet breaks, record their conversations and monitor their online activities. ${ }^{37}$ Some employers now also monitor worker movements outside the workplace, using mobile phones, or worker health and fitness via wearable devices such as Fitbits. Both of these forms of employee surveillance are

34 Sue Shellenbarger, "Work at Home? Your Employer May Be Watching," Wall Street Journal, July 30, 2008, accessed September 20, 2020, https://www.wsj.com/articles/ SB121737022605394845.

35 Tim Cushing, "Another Coronavirus Side Effect: In-Home Surveillance By Remote Workers' Employers," Techdirt, Apr 8, 2020, Accessed September 20, 2020. https://www.techdirt. com/articles/20200401/14133144215/another-coronavirus-side-effect-in-home-surveillanceremote-workers-employers.shtml.

$36 \quad$ Golden and Chemi 2020, "Worker Monitoring Tools.".

37 Ivan Manokha, "The Implications of Digital Employee Monitoring”; Ivan Manokha, "New Means of Workplace Surveillance: From the Gaze of the Supervisor to the Digitalization of Employees, Monthly Review 70, no. 9, 2019, pp. 25-39. 
normalized by telework and and the remote employee monitoring tools that come with it.

In addition, we may add that the rise in 'formal' telework during the pandemic may lead to an increase in 'informal' remote work as well. Thus, it is not implausible to assume that workers returning to their workplaces after lockdowns might be required by employers (or employees themselves might feel compelled) to continue working from home outside normal working hours. Given the current situation in the labour market, which has greatly deteriorated during the pandemic in all countries, this outcome is very likely as the power of employers over employees in periods of high unemployment usually increases.

Finally, it may be suggested that telework, particularly when performed under the supervisor's 'gaze', creates an additional form of alienation. Marx, in his analysis of the wage-labour relation in "The Economic and Philosophical Manuscripts," argued that when a person sells his labour power, he no longer belongs to himself, as part of his energy and time is now a property of the employer. As a result, a worker "does not confirm himself in his work, but denies himself, feels miserable and not happy, does not develop free mental and physical energy, but mortifies his flesh and ruins his mind. Hence the worker feels himself only when he is not working; when he is working he does not feel himself. He is at home when he is not working, and not at home when he is working." 38 Now, in this last sentence Marx of course used 'at home' metaphorically, but if we paraphrase it literally, we may capture an interesting paradox: the worker is at home, but, because he is working, he is also not at home. In other words, it may be said that the employee working remotely and, in particular, when subject to 'domestic surveillance' by the employer is, in a way, alienated from his private space - it is no longer his private home but a workplace to which the employer has some form of access.

\section{Conclusion}

As we have seen, the spike in teleworking during the Covid-19 crisis has generally been seen in academic and non-academic literature as a positive development to be encouraged to develop further in the post-pandemic period. And, it is, indeed, likely that in many individual cases it will bring more flexibility and autonomy to employees.

$38 \quad$ Karl Marx, "The Economic and Philosophical Manuscripts," in Karl Marx - Early Writings (Penguin, Harmondsworth, 1974), 326 (emphasis added). 
However, looked at from a structural perspective - in the context of the changes to the organisation of work in advanced capitalist countries that have been taking place in the last several decades - the development of remote working appears to be problematic. It contributes to the further dissolution of the boundary between professional and private life, to the development of a ' $24 / 7$ employee' or a 'just-in-time employee', who is available, reachable and observable at any time. This tendency is particularly reinforced by the surveillance dispositif that transforms employees' private space into a workplace that the employer has the right to intrude and which, as has been argued above, also results in a new form of alienation - the alienation of workers' from their homes.

We live in a period of increased dominance of work time and schedules over personal or family rhythms, which, as we have seen, are increasingly desynchronized. One of the key aspects of their synchronisation in modernity has been the separation of work from non-work, of the workplace from private home, of the imperatives of work from the imperatives that are governed by biological and physiological rythmes. By contributing to the further erosion of the boundary between work and private life, the rise in telework thereby also contributes to this desynchronization and to all the burdens that come with it.

\section{Bibliography}

Adam, Barbara. Timescapes of Modernity. The Environment and Invisible Hazards. New York: Routledge, 1998.

Adams-Prassl, Abigail, Teodora Boneva, Marta Golin, Christopher Rauh. "Working from Home: The Polarising Workplace." VoxEU.org. September 2, 2020, accessed September 20, 2020. https://voxeu.org/article/working-home-polarising-workplace. Adams-Prassl, Abigail, Teodora Boneva, Marta Golin, Christopher Rauh. "Inequality in the impact of the Coronavirus shock: Evidence from real time surveys." Centre for Economic Policy Research. Discussion Paper 14665. April 2020, accessed September 20, 2020. https://cepr.org/active/publications/discussion_papers/ dp.php?dpno=14665.

Aloisi, Antonio and Elena Gramano. "Workers Without Workplaces and Unions Without Unity: Non-Standard Forms of Employment, Platform Work and Collective Bargaining." Social Science Research Network. March 21, 2019, accessed June 1, 2020. https://papers.ssrn.com/abstract=3363185.

Anttila, Timo and Tomi Oinas. "Patterns of Working Time and Work Hour Fit in Europe." In Family, Work and Well-Being, edited by Tammelin Mia. Cham: Springer International Publishing, 2018. 
Boltanski, Luc, and Ève Chiapello. The New Spirit of Capitalism. London: Verso, 2007.

Braverman, Harry. Labor and Monopoly Capital: The Degradation of Work in the Twentieth Century. New York: Monthly Review Press, 1974.

Burawoy, Michael. Manufacturing Consent: Changes in the Labor Process Under Monopoly Capitalism. Chicago: University of Chicago Press, 1979.

Cappelli, Peter. The New Deal at Work: Managing the Market-Driven Workforce. Boston: Harvard Business School Press, 1999.

Crary, Jonathan. 24/7: Late Capitalism and the Ends of Sleep. London: Verso, 2014.

Cushing, Tim. "Another Coronavirus Side Effect: In-Home Surveillance By Remote Workers' Employers." Techdirt. April 8, 2020, accessed September 20, 2020. https:// www.techdirt.com/articles/20200401/14133144215/another-coronavirus-side-effectin-home-surveillance-remote-workers-employers.shtml.

De Stefano, Valerio. “The Rise of the 'Just-In-Time Workforce': On-demand Work, Crowdwork, and Labor Protection in the 'Gig-economy'. Comparative Labor Law \& Policy Journal 37, no. 3 (2016): 471-503.

Eurofound. Sixth European Working Conditions Survey. Luxembourg: Publications Office of the European Union, 2015.

Frey, Carl and Michael Osborne. "Technology at Work. The Future of Innovation and Employment." The Oxford Martin School. February 2015, accessed September 20, 2020. https://www.oxfordmartin.ox.ac.uk/downloads/reports/Citi_GPS_Technology_Work. pdf.

Gandini, Alessandro. "Labour Process Theory and the Gig Economy." Human Relations 72, no. 6 (2018): 1039-56.

Golden, Jessica, and Eric Chemi. "Worker Monitoring Tools See Surging Growth as Companies Adjust to Stay-at-Home Orders." CNBC. May, 13, 2020, accessed September 20, 2020. https://www.cnbc.com/2020/05/13/employee-monitoringtools-see-uptick-as-more-people-work-from-home.html.

Lefebvre, Henri. Critique of Everyday Life, Volume 2: Foundations For a Sociology of the Everyday. London: Verso, 2002.

Lefebvre, Henri. Rhythmanalysis: Space, Time, and Everyday Life. London: Continuum, 2004.

Loh, Tracy Hadden and Lara Fishbane. "COVID-19 Makes the Benefits of Telework Obvious." The Brookings Institution. March 17, 2020, accessed September 20, 2020. https://www.brookings.edu/blog/the-avenue/2020/o3/17/covid-19-makes-thebenefits-of-telework-obvious/.

Manokha, Ivan. "The Implications of Digital Employee Monitoring and People Analytics for Power Relations in the Workplace." Surveillance \& Society 18, no. 4 (2020) (forthcoming).

Marx, Karl, The Grundrisse. New York: Harper \& Row, 1972. 
Marx, Karl. "The Economic and Philosophical Manuscripts." In Karl Marx - Early Writings. Harmondsworth: Penguin, 1974.

Marx, Karl, Capital: Volume 1. London: Pelican Books, 1976.

Milasi, Santo, Martina Bisello, John Hurley, Matteo Sostero, Enrique Fernández-Macías. "The Potential for Teleworking in Europe and the Risk of a New Digital Divide." VoxEU.org. August 14, 2020, accessed September 20, 2020. https://voxeu.org/article/ potential-teleworking-europe-and-risk-new-digital-divide.

Reisch, Lucia. "The Role of Time and Temporalities for Sustainable Patterns of Consumption." Time \& Society 10, no. 2/3 (2001): 367-385.

Rosa, Hartmut, Social Acceleration: A New Theory of Modernity. New York: Columbia University Press, 2013.

Shellenbarger, Sue. "Work at Home? Your Employer May Be Watching." Wall Street Journal. July 30, 2008, accessed September 20, 2020. https://www.wsj.com/articles/ SB121737022605394845.

Smith, Andrew, and Jo McBride. "Working to Live, Not Living to Work': Low-Paid Multiple Employment and Work - Life Articulation." Work, Employment and Society, September 2020. https://doi.org/10.1177/o950017020942645.

Standing, Guy. "Understanding the Precariat through Labour and Work Guy Standing." Development and Change 45, no. 5 (2014): 963-980.

Thomas, Daniel, Stephen Morris and AndrewEdgecliffe-Johnson. "TheEnd of the Office? Coronavirus May Change Work Forever." The Financial Times. May 1, 2020 accessed May15, 2020,https://www.ft.com/content/1b30430o-0756-4774-9263-c97958eoo54d.

Thompson, Edward Palmer. “Time, Work-Discipline, and Industrial Capitalism." Past \& Present, no. 38 (Dec., 1967): 56-97.

US Bureau of Labor Statistics. "Employment Situation Summary." May 2019, accessed July 1, 2020, https://www.bls.gov/news.release/empsit.toc.htm.

Veen, Alex, Tom Barratt, and Caleb Goods. "Platform-Capital's 'App-Etite' for Control: A Labour Process Analysis of Food-Delivery Work in Australia." Work, Employment and Society, 34, no. 3 (2020): 388-406.

Wajcman, Judy. Pressed for Time: The Acceleration of Life in Digital Capitalism. Chicago: University of Chicago Press, 2014. 